\title{
Effect of Bacteriocin-Like Substance Produced by Enterococcus faecium EF55 on the Composition of Avian Gastrointestinal Microflora
}

\author{
V. STROMPFOVÁ ${ }^{1}$, A. LAUKOVÁ ${ }^{1}$, D. MUDROŇOVÁ ${ }^{2}$ \\ ${ }^{1}$ Institute of Animal Physiology Slovak Academy of Sciences, Košice, Slovakia \\ ${ }^{2}$ Research Institute of Veterinary Medicine-University of Veterinary Medicine, Košice, Slovakia
}

\author{
Received March 23, 2003
}

Accepted September 22, 2003

\begin{abstract}
Strompfová V., A. Lauková, D. Mudroňová: Effect of Bacteriocin-like Substance Produced by Enterococcus faecium EF55 on the Composition of Avian Gastrointestinal Microflora. Acta Vet. Brno 2003, 72: 559-564.

The influence of daily orally administered crude extract of bacteriocin-like substance (at a concentration of $3200 \mathrm{AU} / \mathrm{ml}$ ) produced by Enterococcus faecium EF55 on the total counts of lactobacilli, staphylococci, enterococci and E. coli in the faeces and caecum of 3-day-old Japanese quails was investigated. Enterococcus faecium EF55 was isolated from the crop content of a chicken (Gallus domesticus). The inhibitory activity of bacteriocin-like substance (BLIS) produced by the strain EF55 was assayed by the agar spot test using Gram-positive and Gramnegative indicator bacteria. A wide range of Gram-positive genera such as Enterococcus, Staphylococcus, Micrococcus, Lactobacillus, Lactococcus, Streptococcus and Aerococcus was susceptible to BLIS, but none of the Gram-negative bacteria. The antimicrobial substance produced by the strain EF55 was thermo-resistant $\left(30 \mathrm{~min}\right.$ at $\left.100{ }^{\circ} \mathrm{C}\right)$, stable at $\mathrm{pH} 4.0$ to 9.0 at $-20{ }^{\circ} \mathrm{C}$, $4{ }^{\circ} \mathrm{C}$ and $22{ }^{\circ} \mathrm{C}$ for $10 \mathrm{~d}$ tested, and inactivated by proteolytic enzymes indicating its proteinaceous nature. After the first administration of bacteriocin crude extract (BCE) of EF55 strain to Japanese quails, a reduction amounting to $0.83-1.3 \log$ cycles of $E$. coli, enterococci, staphylococci and lactobacilli in faeces was observed within $24 \mathrm{~h}$. This inhibitory effect was most visible after first extract addition, later this difference was diminished. By agar spot test, BLIS produced by the strain EF55 of Ent. faecium was active against Staphylococcus spp., Lactobacillus spp. and Enterococcus spp., isolates obtained from the experimental birds. However, no inhibition against $E$. coli was detected, despite of their decreased counts under in vivo conditions.
\end{abstract}

Bacteriocin, Japanese quails, gastrointestinal microflora, effect

The ability of bacteria to produce bacteriocins is well known (Klaenhammer et al. 1993). Bacteriocins are proteinaceous compounds with inhibitory activity against more or less related bacterial genera ( $\mathrm{Nes}$ et al. 1996). Bacteriocin-producing bacteria have been isolated from a variety of habitats (Dykes 1995) and bacteriocins have been characterized from many different bacterial genera, especially from lactic acid bacteria (J a ck et al. 1995). Nisin, produced by certain strains of Lactococcus lactis subsp. lactis, is the best characterized bacteriocin-lantibiotic widely used for decades as a food preservative (Delves-Broughton et al. 1996). More recently, also biomedical applications have been proposed which include its potential to treat mastitis infections in cows (S ears et al. 1995), gingivitis and gastrointestinal infections such as peptic ulcer disease caused by Helicobacter pylori (Blackburn and Projan 1994). Nisin has been proved to modulate the immune system of mice when included in the diet (De Pablo et al. 1999) or of turbot after its intraperitoneal injection (Villamil et al. 2002). Strains of enterococci, including Enterococcus faecium and Ent. faecalis, have also the ability to produce bacteriocins. Numerous studies concerning enterocins (bacteriocins produced by enterococci) have been published during recent ten years. Up to now the following enterocins have been characterized as to their homogenity: enterocin A (Aymerich et al. 1996), enterocin

Address for correspondence:

MVDr. Viola Strompfová

Institute of Animal Physiology,

Šoltésovej 4-6, 04001 Košice, Slovakia
Phone: +421-55-6330283

Fax: +421-55-7287842

http://www.vfu.cz/acta-vet/actavet.htm 
B (Casaus et al. 1997), enterocin P (Cintas et al. 1997), enterocin I (Floriano et al. 1998), enterocin M, a new variant of enterocin P (Mareková et al. 2002), and enterocin CCM 4231 (Lauková et al. 1997). Whereas the effectiveness of enterocins against food spoilage and pathogenic bacteria in various food systems is well demonstrated (Aymerich et al. 2000), little information is available on their possible antagonistic activity in the intestine in vivo. Therefore, the objective of this study was to determine the effect of orally administered bacteriocin-like substance (crude extract), produced by the isolate EF55 of Enterococcus faecium, on the composition of intestinal microflora of conventional Japanese quails. Additionally, antimicrobial activity of this strain against a number of Gram-positive and Gram-negative bacteria was tested.

\section{Materials and Methods}

Experimental animals

A group of fourteen 3-day-old Japanese quails was divided into two groups of seven birds each. The experiment lasted for seven days. All birds were fed the commercial diet BR 1/FAT (Tatrafat s.r. Huncovce, Slovakia) and had access to water ad libitum. The experimental group $(\mathrm{n}=7)$ was orally administered the crude bacteriocin extract of Ent. faecium EF55 at a concentration of $3200 \mathrm{AU} / \mathrm{ml}$ (one oral dose $0.10-0.25 \mathrm{ml}$ ) every 24 hours. The control group $(\mathrm{n}=7)$ was given placebo - Brain heart infusion (BHI) broth (Becton \& Dickinson, Cockeysville, USA). Sampling of faeces was done from each quail after 1,3 and $7 \mathrm{~d}$ to monitor the effect of the bacteriocin crude extract (BCE) on the microflora of their gastrointestinal tract. At the end of the experiment all animals were sacrificed and their caecum was separated. Its content was mixed using Stomacher (80I, England). The birds were weighed both at the beginning and at the end of the experiment.

Bacterial counts

The samples of faeces and caecum content were serially diluted in saline buffer $(0.85 \%)$ according to the standard microbiological method and plated on the following media: Mac Conkey agar (Imuna, Šarišské Michalany, Slovakia) for enumeration of E.coli, Mannitol salt agar (Becton \& Dickinson) for staphylococci, M-Enterococcus agar (Becton \& Dickinson) for enterococci and Rogosa agar (prepared according to Oxoid manufacturer, $\mathrm{pH}$ 6.2) for lactobacilli. Enterococci, staphylococci and E. coli were cultivated at $37^{\circ} \mathrm{C}$ for 24 and $48 \mathrm{~h}$, respectively. Lactobacilli were cultivated in a $3 \% \mathrm{CO}_{2}$ atmosphere at $37^{\circ} \mathrm{C}$ for $48 \mathrm{~h}$. Numbers of colony forming units (cfu) were expressed as $\log 10 \mathrm{cfu}$ per gram. The results are given as arithmetical means \pm S.E.M.

Preparation of crude extract

The bacteriocinogenic strain EF55 of Ent. faecium was grown in $300 \mathrm{ml}$ of BHI broth (Becton \& Dickinson) at $37^{\circ} \mathrm{C}$ for $18 \mathrm{~h}$ (O.D. 60 1.1). Culture supernatant was collected by centrifugation (10000 $\mathrm{g}$ for $30 \mathrm{~min}$ ), neutralized and concentrated in a rotary evaporator. The activity of crude extract was determined by the agar spot test (De Vuyst et al. 1996) on BHI agar plates (1.5 and 0.7\%; Becton \& Dickinson) and expressed in arbitratry units per ml of culture medium $(\mathrm{AU} / \mathrm{ml})$. Arbitrary unit is defined as the reciprocal of the highest dilution giving growth inhibition of the indicator organism. As the indicator was used EA5 strain of Enterococcus avium.

Antimicrobial activity assays

The inhibitory activity of the cell-free supernatant of Ent. faecium EF55 was assayed by the agar spot test (De Vuyst et al. 1996) on BHI agar plates (1.5 and 0.7\%; Becton \& Dickinson) against the target of Gram-positive and Gram-negative bacteria. A complete list of indicator bacteria used in this study is given in Table 1 . The bacteriocin activity of crude extract against strains isolated from the faeces of the experimental quails by using selective growth media mentioned above was also tested by the agar spot test.

Effect of enzymes, pH and heat on bacteriocin activity

Sensitivity to proteolytic enzymes was tested individually at a concetration of $1 \mathrm{mg} / \mathrm{ml}$ by adding of the following enzymes to cell-free supernatant of Ent. faecium EF55: protease (Sigma), trypsin (Sigma), $\alpha$-chymotrypsin (Sigma). Reaction mixtures were incubated at $37^{\circ} \mathrm{C}$ for $1 \mathrm{~h}$.

The thermostability of the antibacterial activity was determined by heating of cell-free neutralized supernatant fluids at $60{ }^{\circ} \mathrm{C}, 80{ }^{\circ} \mathrm{C}$ and $100{ }^{\circ} \mathrm{C}$ for $30 \mathrm{~min}$. To determine the effect of $\mathrm{pH}$ on bacteriocin activity, cell-free supernatant fluid was adjusted to $\mathrm{pH}$ levels ranging from 4.0 to 9.0 (intervals of 1.0) with $1 \mathrm{~N} \mathrm{HCl}$ or $5 \mathrm{~N} \mathrm{NaOH}$. The $\mathrm{pH}$-adjusted supernatants were kept at $-20^{\circ} \mathrm{C}, 4^{\circ} \mathrm{C}$ and room temperature $\left(22^{\circ} \mathrm{C}\right)$ for $10 \mathrm{~d}$. Bacteriocin activity of all tests was determined using agar spot test method and Ent. avium EA5 as indicator.

Statistical analysis

Statistical evaluation of the results was performed by the Students' $t$-test with the level of significance set at $P<0.05$. 
range of $4.0-9.0$ at $-20^{\circ} \mathrm{C}, 4^{\circ} \mathrm{C}$ and room temperature $\left(22^{\circ} \mathrm{C}\right)$ for $10 \mathrm{~d}$ tested. The treatment with proteolytic enzymes (trypsin, $\alpha$-chymotrypsin, protease) resulted in the loss of antibacterial activity, which confirmed the proteinaceous character of this substance. On the basis of these results, it is thermo-stable proteinaceous substance with a stability over a wide range of $\mathrm{pH}$ values such as most of enterocins (Giraffa 1995). Activity of bacteriocins over a wide $\mathrm{pH}$ range is an important asset, allowing their use under acidic conditions (e.g. small intestine, fermented milks) as well as in more neutral enviroments (large intestine, low-acid foods).

The crude bacteriocin extract of strain EF55 (at a concentration of $3200 \mathrm{AU} / \mathrm{ml}$ ) was used in the experiment in vivo. It was daily orally administered to each quail during seven consecutive days. The total counts of selected bacterial groups in the faeces of birds with developing intestinal microflora are summarized in Table 2. After $24 \mathrm{~h}$ of crude extract addition, the total counts of all

Table 2

In vivo effect of bacteriocin crude extract produced by the strain EF55 of Ent. faecium on bacteria in the gastrointestinal tracts of Japanese quails

\begin{tabular}{|c|c|c|c|c|c|c|c|c|}
\hline \multirow[b]{3}{*}{ Day } & \multicolumn{8}{|c|}{$\log 10 \mathrm{cfu} / \mathrm{g}$ of faeces } \\
\hline & \multicolumn{2}{|c|}{ E. coli } & \multicolumn{2}{|c|}{ Enterococcus spp. } & \multicolumn{2}{|c|}{ Lactobacillus spp. } & \multicolumn{2}{|c|}{ Staphylococcus. spp } \\
\hline & $\begin{array}{l}\text { Control } \\
\text { group }\end{array}$ & $\begin{array}{l}\text { Exper. } \\
\text { group }\end{array}$ & $\begin{array}{l}\text { Control } \\
\text { group }\end{array}$ & $\begin{array}{l}\text { Exper. } \\
\text { group }\end{array}$ & $\begin{array}{l}\text { Control } \\
\text { group }\end{array}$ & $\begin{array}{l}\text { Exper. } \\
\text { group }\end{array}$ & $\begin{array}{l}\text { Control } \\
\text { group }\end{array}$ & $\begin{array}{l}\text { Exper. } \\
\text { group }\end{array}$ \\
\hline 0 & 6.82( & $(0.41)$ & 6.67 & $(0.37)$ & 7.84 & $(0.46)$ & 3.52 & $(0.34)$ \\
\hline 1 & $8.12(0.30)^{\mathrm{a}}$ & $7.09(0.31)^{*}$ & $7.79(0.41)$ & $6.63(0.33)^{*}$ & $8.36(0.29):$ & $7.06(0.22)^{* *}$ & $3.83(0.30)$ & $3.00(0.41)$ \\
\hline 3 & $8.62(0.27)$ & $7.72(0.39)$ & $8.00(0.15)$ & $7.73(0.37)$ & $9.12(0.32)$ & $7.81(0.35)^{*}$ & $4.42(0.35)$ & $3.41(0.30)^{*}$ \\
\hline 7 & $8.54(0.30)$ & $7.73(0.31)$ & $7.96(0.27)$ & $7.61(0.39)$ & $9.10(0.38)$ & $7.80(0.49)$ & $3.97(0.48)$ & $3.75(0.38)$ \\
\hline $7^{\mathrm{b}}$ & $8.71(0.27)$ & $8.53(0.35)$ & $8.12(0.37)$ & $7.86(0.33)$ & $9.30(0.46)$ & $8.10(0.45)$ & $3.71(0.47)$ & $3.10(0.26)$ \\
\hline
\end{tabular}

a the values in parentheses are standard errors means

$\mathrm{b}$ Total bacterial count detected in caecum content

$* \mathrm{P}<0.05 \quad * * \mathrm{P}<0.01$

bacterial groups under study (enterococci, staphylococci, lactobacilli and E. coli) were lower compared with control group. The greatest cell count reduction (significant difference) was detected after the first administration of BCE except for the greatest reduction of total counts of staphylococci (difference of $1.01 \log ; P<0.05$ ) detected $72 \mathrm{~h}$ after first BCE administration. Lactobacilli were significantly $(P<0.01)$ reduced $24 \mathrm{~h}$ after first BCE application (difference of $1.30 \mathrm{log}$ ), and this reduction was relatively stable during the experiment. The total count of enterococci was significantly $(P<0.05)$ lower only after the first BCE application (difference of $1.16 \log$ ). The difference in the counts of $E$. coli between experimental and control groups was $1.03 \log (P<0.05)$ also on $d 1$, later it was diminished. Concerning the total counts of cells, staphylococci were the most inhibited bacterial group (reduction of $22.9 \%$ ), followed by lactobacilli (15.6\%), enterococci $(14.9 \%)$ and E. coli $(12.7 \%)$. In the contents of caecum, no significant difference in the total counts of bacterial genera was detected. No differences in body mass between the control and experimental groups were noted.

By the testing of BCE of EF55 in vitro against the isolates from the faeces of quails obtained before experimental treatment (Table 3), a similar, most pronounced inhibitory effect was noted against Staphylococcus spp., followed Lactobacillus spp. and Enterococcus spp. Surprisingly, no inhibition against the isolates of E.coli was detected, despite of their reduction under in vivo conditions. This could be due to secondary interactions between intestinal microflora groups. Moreover, activity of enterocins towards Gram-negative bacteria like $E$. coli (Tomita et al. 1997) and Vibrio cholerae has been shown (Simonetta et al. 1997).

Many bacterial species inhabitating the animal gut produce compounds that are inhibitory, in vitro, to the growth of other bacteria (Du Toit et al. 2000). Many investigators have considered 
Table 3

In vitro inhibition of bacteriocin crude extract of EF55 strain against isolates from the faeces of experimental J. quails

\begin{tabular}{|l|c|c|}
\hline & \multicolumn{2}{|c|}{$\begin{array}{c}\text { Number of strains } \\
\text { Species }\end{array}$} \\
tested & inhibited, \% \\
\hline Staphylococcus spp. & 15 & 73.3 \\
Lactobacillus spp. & 15 & 33.3 \\
Enterococcus spp. & 15 & 26.7 \\
Escherichia coli & 15 & 0.0 \\
\hline
\end{tabular}

the possibility that these compounds influence the survival of a bacterium in an ecological niche in the gastrointestinal tract of animals. In our experiment, the bacteriocin-like substance produced by the strain EF55 of Ent. faecium was able to reduce the populations of present intestinal microflora in experimental birds, although this effect was especially remarkable after its first oral administration. Similarly, this type of inhibition kinetics has been observed before with Listeria as indicator and nisin, pediocin AcH and enterococcin EFS2 as antimicrobial substances (Song and Richard 1997), and may indicate that sensitive bacteria become resistant to the bacteriocin. It is generally admitted that each bacteriocin-sensitive bacterial population includes potentially tolerant and/or resistant cells with structural modifications or at least with a high predisposition to such modifications, which would allow them to spontaneously emerge in case of exposure to the bacteriocin (Hanlin et al. 1993). In particular, modifications in the cytoplasmic membrane composition are often investigated to explain bacteriocin resistance, considering the key role of the membrane in the activity of bacteriocins (Mazzotta and Montville 1997). Because the occurrence of bacteriocin tolerance and/or resistance is the main limiting factor for bacteriocin effectiveness, the use of a combination of several bacteriocins could prevent or delay the apparition of bacteriocin-resistant mutants (Morency et al. 2001).

In conclusion, bacteriocins produced by intestinal Enterococcus isolates may help to control the autochthonous microflora and may be advantageous to the producing strain for its establishment and competition in the gastrointestinal tract. Further studies on bacteriocins behaviour in the intestinal environment are required to determine their suitability for potential biomedical applications where they may provide valuable alternatives to antibiotics for the treatment of animal infections without any side effects and leaving residues in the animal products behind.

\section{Účinok bakteriocin-like substancie produkovanej kmeňom Enterococcus faecium} EF55 na zloženie gastrointestinálnej mikroflóry

$\mathrm{V}$ práci bol sledovaný účinok orálne aplikovaného hrubého extraktu bakteriocin-like substancie (konc. $3200 \mathrm{AU} / \mathrm{ml}$ ), produkovanej kmeňom Enterococcus faecium EF55, na celkové počty laktobacilov, stafylokokov, enterokokov a $E$. coli v truse a céku trojdňových japonských prepelíc. Enterococcus faecium EF55 bol izolovaný z obsahu hrvola kurčata. Pomocou agar spot testu bola sledovaná inhibičná aktivita bakteriocin-like substancie (BLIS) proti niektorým Gram-pozitívnym a Gram-negatívnym baktériám. Na túto substanciu bolo citlivé široké spektrum Gram-pozitívnych baktérií, ako sú baktérie z rodu Enterococcus, Staphylococcus, Micrococcus, Lactobacillus, Lactococcus, Streptococcus a Aerococcus , ale žiadna z Gram-negatívnych baktérií. Bakteriocin-like substancia je relatívne termorezistentná $\left(30\right.$ min pri $\left.100^{\circ} \mathrm{C}\right)$, stabilná pri $\mathrm{pH} 4,0-9,0$ a súčasne teplote $-20^{\circ} \mathrm{C}, 4^{\circ} \mathrm{C}$ a $22^{\circ} \mathrm{C}$ počas 10 dní testovania a inaktivovatelná proteolytickými enzýmami, čo poukazuje na jej proteínový charakter. U prepelíc bola 24 h po prvej aplikácii tejto substancie pozorovaná redukcia v rozsahu 0,83-1,3 log u všetkých sledovaných skupín baktérií (enterokoky, laktobacily, stafylokoky, E. coli). Inhibičný účinok bol najzretelnejší po prvej aplikácii, neskôr postupne slabol. Podobne bola zaznamenaná inhibičná aktivita in vitro (agar spot test) proti rodom Staphylococcus, Lactobacillus a Enterococcus - izolátom z pokusnej skupiny zvierat. Inhibícia proti E.coli nebola detegovaná, napriek ich poklesu za in vivo podmienok. 


\section{Acknowledgements}

This study was supported by the project VEGA 2/2043/23 of Slovak Scientific Agency. The excellent technical assistance of Margita Bodnárová is gratefully acknowledged.

\section{References}

AYMERICH, T, HOLO, H, HÅVARSTEIN, LS, HUGAS, M, GARRIGA, M, NES, IF 1996: Biochemical and genetic characterization of enterocin A from Enterococcus faecium, a new antilisterial bacteriocin in the pediocin family of bacteriocins. Appl Environ Microbiol 62: 1676-1682

AYMERICH, T, GARRIGA, M, YLLA, J, VALLIER, J, MONFORT, JM, HUGAS, M 2000: Application of enterocins as biopreservatives against Listeria innocua in meat products. J Food Prot 63: 721-726

BLACKBURN, P, PROJAN, SJ 1994: Pharmaceutical bacteriocin combinations and methods for using the same. United States Patent, No: 5,304,540. Appl. Microbiol. Inc New York USA

CASAUS, P, NILSEN, T, CINTAS, LM, NES, IF, HERNÁNDEZ, PE, HOLO, H 1997: Enterocin B, a new bacteriocin from Enterococcus faecium T136 which can act synergistically with enterocin A. Microbiol 143: 2287-2294

CINTAS, LM, CASAUS, P, HÅVARSTEIN, LV, HERNÁNDEZ, PE, NES, IF 1997: Biochemical and genetic characterization of enterocin P, a novel sec-dependent bacteriocin from Enterococcus faecium $\mathrm{P} 13$ with a broad antimicrobial spectrum. Appl Environ Microbiol 63: 4321-4330

DE PABLO, MA, GAFORTIO, JJ, GALLEGO, A, ORTEGA, E, GÁLVEZ, AM, ALVAREZ DE CIENFUEGOS LÓPEZ, G 1999: Evaluation of immunomodulatory effects of nisin-containing diets on mice. FEMS Immunol. Med Microbiol 24: 35-42

DE VUYST, L, CALLEWAERT, R, POT, B 1996: Characterization of antagonistic activity of Lactobacillus amylovorus DCE471 and large-scale isolation of its bacteriocin amylovorin L471. Syst Appl Microbiol 19: 9-20

DELVES-BROUGHTON, J, BLACKBURN, P, EVANS, RJ, HUGENHOLTZ, J 1996: Applications of the bacteriocin, nisin. Ant Van Leewen 69: 193-202

DU TOIT, M, FRANZ, CMAP, DICKS, LMT, HOLZAPFEL, WH 2000: Preliminary characterization of bacteriocins produced by Enterococcus faecium and Enterococcus faecalis isolated from pig faeces. J Appl Microbiol 88: 482-494

DYKES, GA 1995: Bacteriocins: ecological and evolutionary significance. Trends Ecol Evol 10: 186-189

FLORIANO, B, RUIZ-BARBA, JL, JIMÉNEZ-DÍAZ, R 1998: Purification and genetic characterization of enterocin I from Enterococcus faecium 6T1a, a novel antilisterial plasmid-encoded bacteriocin which does not belong to the pediocin family of bacteriocins. Appl Environ Microbiol 64: 4883-4890

GIRAFFA, G 1995: Enterococcal bacteriocins: Their potential as anti-Listeria factors in dairy technology. Food Microbiol 12: 291-299

HANLIN, MB, KALCHAYANAND, N, RAY, P, RAY, B 1993: Bacteriocins of lactic acid bacteria in combination have greater antibacterial activity. J Food Prot 56: 252-255

JACK, RW, TAGG, JR, RAY, B 1995: Bacteriocins of Gram-positive bacteria. Microbiol Rev 59: 171-200

KLAENHAMMER, TR 1993: Genetics of bacteriocins produced by lactic acid bacteria. FEMS Microbiol Rev 12: 39-86

LAUKOVÁ, A, MAREKOVÁ, M, DOBRÁNSKY, T, CZIKKOVÁ, S, JAVORSKÝ, P 1997: Production and characteristic of bacteriocins of rumen associated anterococci. In: Abstracts of Joint RRI-INRA Rumen Microbiology Symposium: Evolution of the rumen Microbial Ecosystem, March Aberdeen UK, p.5

MAREKOVÁ, M, LAUKOVÁ, A, SKAUGEN, M, NES, IF 2002: Isolation and characterization of a new bacteriocin, termed enterocin M, produced by Enterococcus faecium AL41. Appl. Environ. Microbiol., in press

MAZZOTTA, AS, MONTVILLE, TJ 1997: Nisin induces changes in membrane fatty acid composition of Listeria monocytogenes nisin-resistant strains at $10^{\circ} \mathrm{C}$ and $30^{\circ} \mathrm{C}$. $\mathrm{J}$ Appl Bacteriol 82: $32-38$

MORENCY, H, MOTA-MEIRA, M, LAPOINTE, G, LACROIX, CH, LAVOIE, MC 2001: Comparison of the activity spectra against pathogens of bacterial strains producing a mutacin or a lantibiotic. Can J Microbiol 47: 322-331

NES, IF, DIEP, DB, HAVARSEIN, LS, BRURBERG, MB, EIJSINK, V, HOLO, H 1996: Biosynthesis of bacteriocins in lactic acid bacteria. Ant van Leewen 70: 113-128

SEARS, PM, PEELE, J, LASSAUZET, M, BLACKBURN, P 1995: Use of antimicrobial proteins in the treatment of bovine mastitis. In: Proceeding of the $3^{\text {rd }}$ International Mastitis seminar, pp. 17-18

SIMONETTA, AC, DE VELASCO, MLG,FRISÓN, LN 1997: Antibacterial activity of enterococci strains against Vibrio cholerae. Lett. Appl. Microbiol. 24: 139-143

SONG, H.-Y., RICHARD, J. 1997: Antilisterial activity of three bacteriocins used at sub minimal inhibitory concentrations and cross-resistance of the survovors. Int J Food Microbiol 36: 155-161

TOMITA, H, FUJIMOTO, S, TANIMOTO, K, IKE, Y 1997: Cloning and genetic organization of the bacteriocin 21 determinant encoded on the Enterococcus faecalis pheromone-responsive conjugative plasmid pPD1. J Bacteriol 179: 7843-7855

VILLAMIL, L, FIGUERAS, A, NOVOA, B 2002: Immunomodulatory effects of nisin in turbot (Scophthalmus maximus L.). Fish Shellfish Immunol 12: 000-000 